\title{
Hoya daimenglongensis (Apocynaceae, Asclepiadoideae), a New Species from Yunnan, China
}

\author{
Shao-yun He, ${ }^{1}$ Wei Wu, ${ }^{2}$ Ping-tao Li, ${ }^{3 *}$ and Mei-ling Zeng ${ }^{1}$
}

${ }^{1}$ Key Laboratory of Innovation and Utilization for Germplasm Resources in Horticultural Crops in Southern China of Guangdong Higher Education Institutes, College of Horticulture, South China Agricultural University, Guangzhou 510642, People's Republic of China. syhe2001@163.com

2 State Key Laboratory of Biocontrol and Key Laboratory of Gene Engineering of the Ministry of Education, Sun Yat-Sen University, Guangzhou 510275, People's Republic of China

3 College of Forestry, South China Agricultural University, Guangzhou 510642,

People's Republic of China

*Author for correspondence: Li85280485@126.com

AbSTRact. Hoya daimenglongensis Shao Y. He \& P. T. Li (Apocynaceae, Asclepiadoideae) from Yunnan Province, China, is described and illustrated. This new species and $H$. linearis Wall. ex D. Don are similar in their linear leaves and terminal inflorescences. Hoya daimenglongensis, however, differs from $H$. linearis by the internal surface of the corolla, which is minutely tomentose and not papillose (vs. glabrous or papillose), and the corona lobes, which are white tinged with red (vs. pure white).

Key words: Apocynaceae, Asclepiadoideae, China, Hoya, IUCN Red List, Yunnan.

Among the Asclepiadoideae (Apocynaceae), Hoya caronsa (L. f.) R. Br. was established as the type of Hoya R. Br. by Brown in 1810 (Brown, 1810) and was collected from China (Linnaeus, 1782; Tsaing \& $\mathrm{Li}, 1977)$. China is a significant center of diversification among Hoya, which has a worldwide distribution. Tsiang and Li (1977) recognized 22 species, three varieties, and two forms for Hoya in China. Later, Li et al. (1995) described 32 species and one variety in China, of which 17 Hoya species were endemic (Gilbert et al., 1995). Three species have since been recently described from Hainan Island, south of China, by He et al. (2009a, 2009b, 2009c), increasing the number of species of Hoya in China to 35. India and Malaysia remain major areas of species diversity for Hoya in the world, with as many as 74 estimated for New Guinea (Rintz, 1978; Jagtap \& Singh, 1999; Forster, 2006). Although the majority of Hoya species twine, there are a small number that are pendent, or erect and non-twining, e.g., H. linearis Wall. ex D. Don.

Yunnan Province is particularly diverse for Chinese species of Hoya (He et al., 2009a). The first author made an interesting collection of a flowering
Hoya that exhibited a striking pendent habit during a 2009 botanical trip to Damenglong in Yunnan. Based on the field observations, comparison with specimens at CANT, HITBC, IBSC, K, KUN, MO, P, and PE, and literature survey (Hooker, 1885; Costantin, 1912; Tsiang \& Li, 1974, 1977; Rintz, 1978; Li, 1994; Gilbert et al., 1995; Li et al., 1995; Forster \& Liddle, 1996; Jagtap \& Singh, 1999), the collection appears to be a new species of Hoya, which is described herein. This new species appears to be allied to the pendent species $H$. linearis that is widely distributed in China, Nepal, India, and Myanmar (Don, 1825; Hooker, 1885; Li et al., 1995; Jagtap \& Singh, 1999). The holotype of $H$. linearis was collected from Nepal (Don, 1825), and the linear blades of this species are among the smallest in Hoya, no more than $5 \mathrm{~cm}$ long and $0.5 \mathrm{~cm}$ wide.

Hoya daimenglongensis Shao Y. He \& P. T. Li, sp. nov. TYPE: China. Yunnan: Daimenglong, on trees in montane tropical rainforest, $1200 \mathrm{~m}, 21$ Aug. 2009, S. Y. He 09080216 (holotype, CANT, CANT photo at MO; isotype, CANT). Figure 1.

Haec species Hoyae lineari Wall. ex D. Don foliis linearibus ac inflorescentia terminali similis, sed ab ea corollis intrinsecus tomentellis epapillatis atque coronarum lobis albis rubrotinctis ad angulum externum rotundatis differt.

Epiphytic plants, with milky latex; stems pendent to $1 \mathrm{~m}$, green, villose, slender, $0.2-0.3 \mathrm{~cm}$ diam.; internodes $2-3 \mathrm{~cm}$. Leaves decussate, fleshy; leaf blades linear, adpressed, 4.5-6 × 0.2-0.5 cm, 0.2$0.3 \mathrm{~cm}$ thick; base cuneate, \pm acute or mucronate at apex; blades adpressed to stem, villose, green, with the margin revolute, white; blade midrib abaxially 

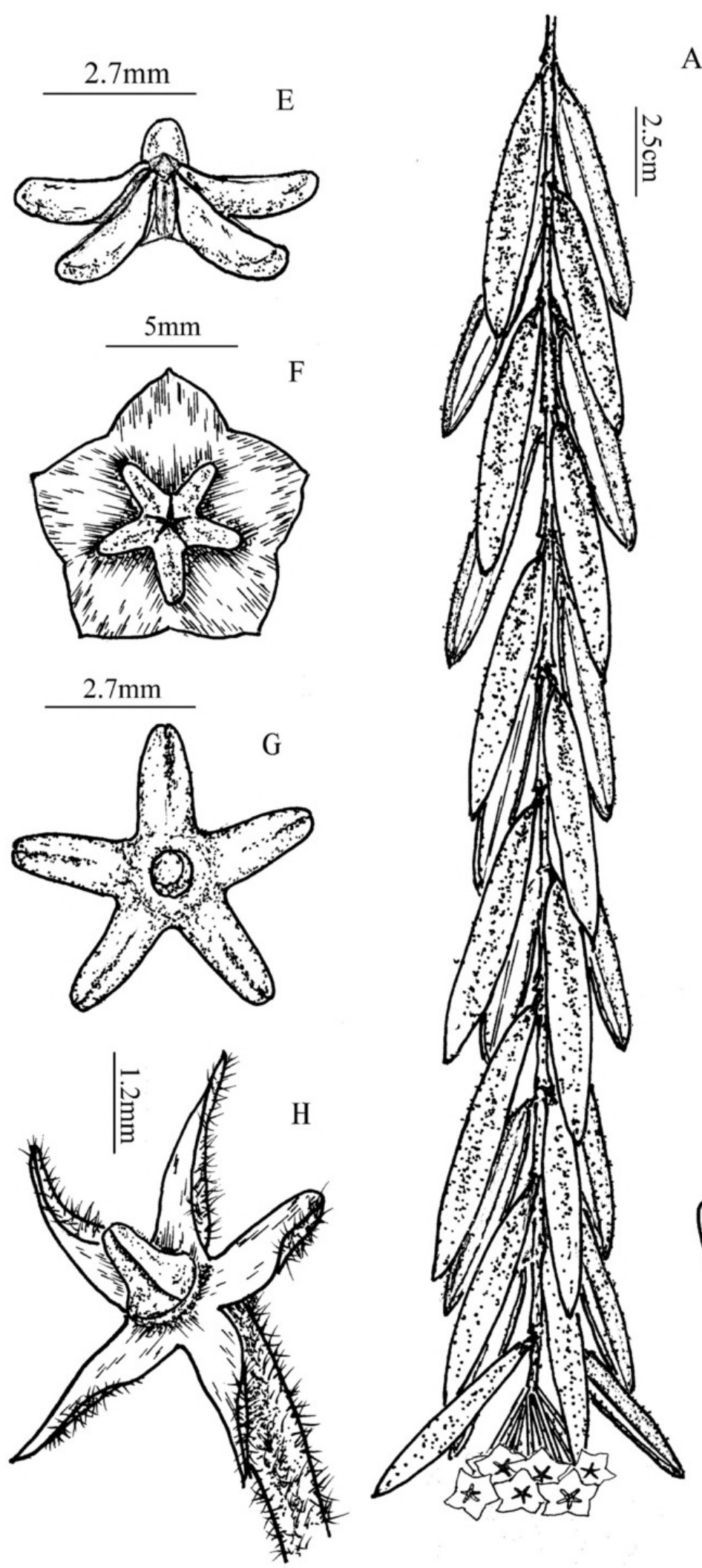

A

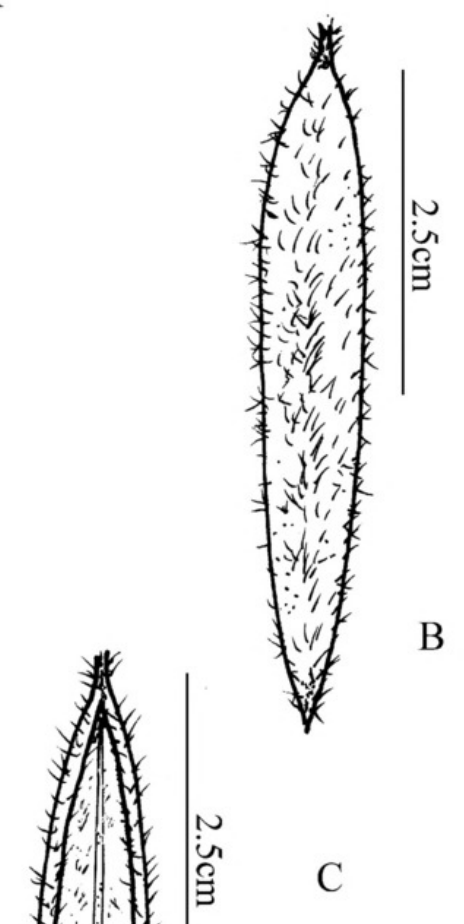

D
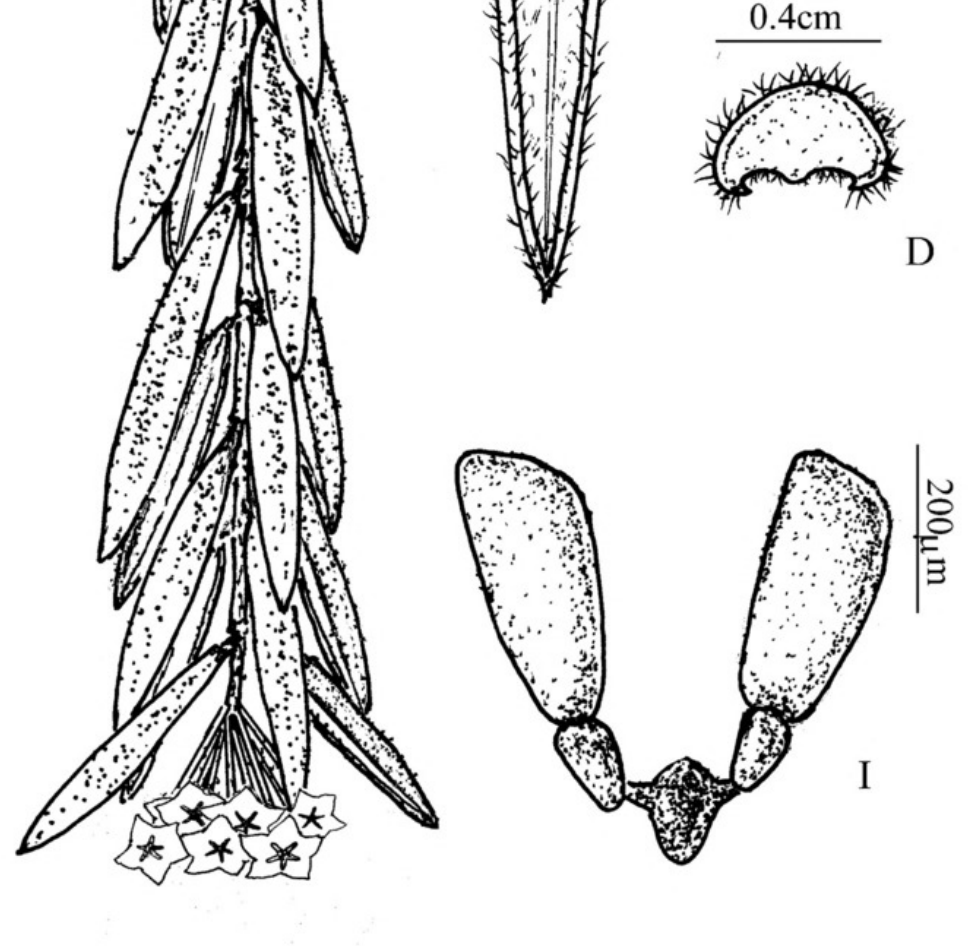

Figure 1. Hoya daimenglongensis Shao Y. He \& P. T. Li. - A. Fertile, pendent habit. —B. Adaxial leaf blade, showing the pubescent, green, rounded surface. - C. Abaxial leaf blade, showing the white, recurved margins and midrib. -D. Cross section of leaf blade. - E. Side view of corona. - F. Intact flower seen from above. —G. Outer corona. — H. Pedicel, calyx, and ovaries. - I. Pollinarium. A-I drawn from the holotype S. Y. He 09080216 (CANT) by Shao-yun He. 
evident, green; blade adaxially rounded; lateral veins not visible; petiole deep green, villose, brief, only to $0.2-0.3 \mathrm{~cm}$. Inflorescences terminal, pendent, convex pseudoumbels, ca. 9-flowered; peduncle green, villose, ca. $0.4 \mathrm{~cm}$; pedicels yellowish white, villose, $1.5-2 \mathrm{~cm}$. Flowers with the sepals light yellow, externally villose; narrowly triangular, $2.2 \times 0.6 \mathrm{~mm}$, apex acuminate; corolla white, externally glabrous, internally minutely tomentose and not papillate, slightly deflexed, ca. 1.2-1.5 cm diam., lobes ca. 2.6-3.2 mm, margins recurved, apex cuspidate; corona with 5 white lobes, but lobes are red-tinged on outer angles and alternate with the lower corolla lobes; lobes resembling rice grains, somewhat cylindrical, ca. $2.5 \times 1.1 \mathrm{~mm}$, inner angles erect, subacute, prominent on upper surface, lobe outer angle rounded; stamens 5, adnate to gynostegium, anthers obliquely positioned below the upper corona lobes, with a stigmatic head; pollinium broad, caudicle ca. $75 \mu \mathrm{m}$ wide, $90 \mu \mathrm{m}$ high; corpusculum similar, fusiform, dark brown; ovaries paired, superior, $1.3 \mathrm{~mm}$ high, $1 \mathrm{~mm}$ diam. Fruit and seeds unknown.

Distribution and habitat. Hoya daimenglongensis is found in Damenglong, Jinghong City, in southern Yunnan Province, China. The new taxon was observed to grow in tropical montane forest at $1200 \mathrm{~m}$ elevation. Associated species include Horsfieldia tetratepala C. Y. Wu \& W. T. Wang (Myristicaceae); Wendlandia uvariifolia Hance (Rubiaceae); Ficus pumila L. (Moraceae); Mallotus nepalensis Müll. Arg., Croton tiglium L., Mallotus paniculatus (Lam.) Müll. Arg., and Glochidion arborescens Blume (all Euphorbiaceae); Hicriopteris chinensis (Rosenst.) Ching (Gleicheniaceae); Alsophila podophylla Hook. (Cyatheaceae); Murdannia triquetra G. Brückn. (Commelinaceae); Monstera deliciosa Liebm. (Araceae); and Buddleja lindleyana Fortune (Loganiaceae). Two other species of Hoya are recorded from the same area: $H$. chinghungensis (Tsiang \& P. T. Li) M. G. Gilbert, P. T. Li \& W. D. Stevens and H. lyi H. Lév.

IUCN Red List category. Hoya daimenglongensis is currently known only from the type locality; beyond this, there is lack of additional information. For now, the species should be classified as Data Deficient (DD), according to IUCN Red List criteria (IUCN, 2001).

Phenology. Hoya daimenglongensis was collected with flowers in August. The fresh flowers have a noticeable fragrance.
Etymology. The new species' epithet refers to the type locality in Damenglong, Yunnan Province, China.

Discussion. Hoya daimenglongensis is characterized by the internal surface of the corolla being minutely tomentose and lacking papillae, and by the white corona lobes rounded and tinged with red at the outer angles. This species could be most confused with the morphologically similar $\mathrm{H}$. linearis, with both taxa having linear and pubescent leaf blades of similar size (slightly shorter in $H$. linearis, 2.5-5 $\times$ $0.5 \mathrm{~cm}$ ), with the entire abaxial surface whitened, but the adaxial surface otherwise green. The two species also share a pendent habit and terminal inflorescences. Petioles are brief, no more than $3 \mathrm{~mm}$, in both species, but villose in $H$. tsiangyingiana and hirsute in H. linearis. Hoya linearis, however, is easily distinguished by its glabrous or internally papillose corolla, by the corona lobes that are completely white, and by its broader distribution beyond China, ranging into Nepal, India, and Myanmar.

Three species, Hoya linearis, H. chinghungensis, and $H$. lyi, are sympatric in Yunnan Province with $H$. daimenglongensis. The following key should aid in the identification of the four species.

Key to Four Species of Hoya in Yunnan Province, China

1a. Pseudoumbels terminal $\ldots \ldots \ldots \ldots \ldots \ldots \ldots \ldots$

2a. Leaf blades linear.$\ldots \ldots \ldots \ldots \ldots \ldots \ldots \ldots \ldots \ldots$

3a. Corolla internal surface glabrous or papillose; outer angles of corona lobes acute, white ...... H. linearis

$3 \mathrm{~b}$. Corolla internal surface tomentose, nonpapillose; outer angles of corona lobes round, tinged red . H. daimenglongensis

2b. Leaf blade broadly ovate, $1-1.5 \mathrm{~cm}$, lateral veins obsolete .................... chinghungensis

1b. Pseudoumbels extra-axillary; leaf blades elliptic, oblong, or elliptic-lanceolate, rarely suborbicular, (3-)5.5-19 cm, lateral veins in 4 to 7 pairs

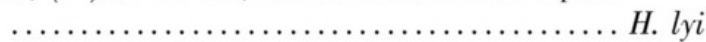

Paratype. CHINA. Yunan: Daimenglong, on trees in montane tropical rainforest, $1200 \mathrm{~m}, 21$ Aug. 2009, S. Y. He 09080217 (CANT).

Acknowledgments. The authors are grateful to Xishuangbanna Tropical Botanical Garden and the Kunming Institute of Botany, Chinese Academy of Sciences. We also thank Xiao-ying $\mathrm{Wu}$ of South China Agricultural University for assistance with the morphological analysis of Hoya species. This work was supported by funds from Guangdong Province, from the China Science and Technology Project (grant numbers 2003C201020, 2007A020300009-7, and 2008B020400016). 


\section{Literature Cited}

Brown, R. 1810. On the Asclepiadeae, Prodromus florae Novae Hollandiae et Insulae Van-Diemen, exhibens characteres plantarum. Typis R. Taylor et socii, London. 1: 459-460.

Costantin, J. 1912. Hoya. Pp. 125-141 in Flore Générale de l'Indo-Chine, Vol. 4. Masson \& Cie, Paris.

Don, D. 1825. Prodromus Florae Nepalensis. J. Gale, London.

Forster, P. I. 2006. The asclepiad flora of New Guinea. Pp. 371-378 in A. J. Marshall \& B. M. Beehler (editors), The Ecology of Papua. Periplus Editions, Singapore.

Forster, P. I. \& D. J. Liddle. 1996. Hoya. Pp. 235-237 in A. E. Orchard (editor), Flora of Australia, Vol. 28. CSIRO, Melbourne.

Gilbert, M. G., W. D. Stevens \& P. T. Li. 1995. Notes on the Asclepiadaceae of China. Novon 5: 1-16.

He, S. Y., X. Y. Zhuang, P. T. Li, J. Y. Lin \& M. Li. 2009a. Hoya baishaensis (Apocynaceae), a new species from Hainan, China. Ann. Bot. Fenn. 46(2): 155-158.

He, S. Y., P. T. Li, J. Y. Lin \& M. L. Zeng. 2009b. A new species of Hoya (Apocynaceae, Asclepiadoideae) from Hainan, China. Novon 19(3): 357-359.

He, S. Y., P. T. Li, J. Y. Lin \& X. H. Yang. 2009c. Hoya persicinicoronaria (Apocynaceae, Asclepiadoideae), a new species from Hainan, China. Novon 19(4): 475-478.
Hooker, J. D. 1885. Hoya Br. Pp. 52-62 in Flora of British India, Vol. 4. Reeve \& Co., London.

IUCN. 2001. IUCN Red List Categories and Criteria, Version 3.1. Prepared by the IUCN Species Survival Commission. IUCN, Gland, Switzerland, and Cambridge, United Kingdom.

Jagtap, A. P. \& N. P. Singh. 1999. Hoya. Pp. 91-122 in Fascicles of Flora of India, Vol. 24. Botanical Survey of India, Calcutta.

Li, P. T. 1994. Three new species of Hoya (Asclepiadaceae) from Myanmar. J. S. China Agric. Univ. 15(2): 73-76.

Li, P. T., M. G. Gilbert \& W. D. Stevens. 1995. Asclepiadaceae. Pp. 190-236 in Z. Y. Wu \& P. H. Raven (editors), Flora of China, Vol. 16. Science Press, Beijing, and Missouri Botanical Garden, St. Louis.

Linnaeus, C. V. f. 1782. Asclepias L. Pp. 169-170 in Supplementum Plantarum. Orphanotrophe, Braunschweig, Germany.

Rintz, R. E. 1978. The peninsular Malaysian species of Hoya (Asclepiadaceae). Malayan Nat. J. 30(3-4): 467522 .

Tsiang, Y. \& P. T. Li. 1974. Prasecursores Florae Asclepiadacearum Sinensium. Acta Phytotax. Sin. 12: 120-127.

Tsiang, Y. \& P. T. Li. 1977. Hoya. Pp. 475-492 in Y. Tsiang \& P. T. Li (editors), Flora Reipublicae Popularis Sinicae, Vol. 63. Science Press, Beijing. 


\section{$2 \mathrm{BHL}$ Biodiversity Heritage Library}

He, Shao-Yun et al. 2012. "Hoya daimenglongensis (Apocynaceae, Asclepiadoideae), a New Species from Yunnan, China." Novon a journal of botanical nomenclature from the Missouri Botanical Garden 22(2), 170-173. https://doi.org/10.3417/2010020.

View This Item Online: https://www.biodiversitylibrary.org/item/196082

DOI: https://doi.org/10.3417/2010020

Permalink: https://www.biodiversitylibrary.org/partpdf/218554

\section{Holding Institution}

Missouri Botanical Garden, Peter H. Raven Library

\section{Sponsored by}

Missouri Botanical Garden

\section{Copyright \& Reuse}

Copyright Status: Permission to digitize granted by rights holder

Rights: https://www.biodiversitylibrary.org/permissions

This document was created from content at the Biodiversity Heritage Library, the world's largest open access digital library for biodiversity literature and archives. Visit BHL at https://www.biodiversitylibrary.org. 